\section{Determinants of Hoophouse Profitability: A Case Study of 12 Novice Michigan Farmers}

\author{
Kurt B. Waldman ${ }^{1}$, David S. Conner ${ }^{2,4}$, John A. Biernbaum ${ }^{3}$, \\ Michael W. Hamm ${ }^{1}$, and Adam D. Montri ${ }^{3}$
}

AdDITIONAL INDEX WORDs. season extension, vegetable production, farm management

Summary. Quantitative and qualitative data from a group of 12 novice hoophouse farmers over a 3-year period in Michigan were analyzed to better understand factors associated with profitable use of these structures. There was wide variation in labor inputs and effective wages. We used regression analysis and semistructured interviews to better understand the variation in performance. Not all farmers were making use of the hoophouse between outdoor seasons when supply is low and prices are high, as economic theory would predict. However, high wage earners were more likely to push production into the extended season months, hire labor at higher wages, and spend less time in maintaining crops and appeared to harvest more efficiently. Markets played a role in farmers' success as some farmers were able to make significant profits by organizing community-supported agriculture (CSA)/ direct sales or by finding new markets.

$\mathrm{H}$ oophouses, high tunnels, or unheated greenhouses have been demonstrated to be effective tools for season extension in colder climates such as in Michigan. Hoophouses allow farmers to produce crops at both ends of the regular growing season [e.g., April/May and September/October (hereafter called shoulder months)] and cold-tolerant crops in winter months, potentially leading to year-round profits. Previous economic studies on hoophouses have typically focused on single crop profitability (Cheng and Uva, 2008; Heindenreich et al., 2009) or on-farm enterprise budgets (Blomgren and Frisch, 2007), but few, if any, have examined the profitability of hoophouses used by small farmers who adopted the tool at similar times and used it to grow and sell produce through direct markets such as farmer's

Research and outreach efforts are supported by the National Research Initiative of the U.S. Department of Agriculture Cooperative State Research, Education, and Extension Service, grant number 200655618-16922; the Michigan Agricultural Experiment Station; Michigan State University Extension; and the C.S. Mott Professor of Sustainable Agriculture Endowment.

${ }^{1}$ Department of Community, Agriculture, Recreation and Resource Studies, Michigan State University, 131 Natural Resources Building, East Lansing, MI 48824

${ }^{2}$ Department of Community Development and Applied Economics, University of Vermont, 205H Morrill Hall, 146 University Place, Burlington, VT 05045

${ }^{3}$ Department of Horticulture, Michigan State University, 288 Plant and Soil Science Building, East Lansing, MI 48824

${ }^{4}$ Corresponding author. david.conner@uvm.edu. markets, CSA arrangements, and onfarm markets.

In this article, we look at the management and economic outcomes of primarily hoophouse vegetable production from the perspective of novice hoophouse growers. There are various reasons why more traditional budgeting methods may fall short in guiding profitable hoophouse use. Modeling diversified crop hoophouse production is similar to modeling an intensively managed diversified whole farm: it is challenging to model profitability on a revenue per-square foot basis (as is more common in floriculture/greenhouses) or to make comparisons with crop rotations on a per-acre basis over the course of 1 year (such as a linear programming approach as is more common in agriculture economics). Additionally, the hoophouses allow farmers to cultivate year-round, and so it is also difficult to define the beginning and end of a season. Further complications include labor costs, which occur in very small and difficult to measure time increments. Also, many crops (as many as five) are often cultivated in succession in a single location over the course of 1 year.
The traditional outdoor growing season in Michigan is April through September, so the extended season can be conceptualized as running from October to March. A hoophouse theoretically allows a farmer to grow or harvest the year-round, making economic profits in extended season months, which a farmer without a hoophouse is unable to produce. Because of a higher volume of local produce on the market in summer months, and thus greater competition during the traditional growing season, we would expect hoophouse farmers to maximize the potential of the hoophouse by allocating labor to produce extended season crops and even winter crops. Therefore, we would expect the marginal value product of the labor to be higher in the shoulder months. However, because most of the hoophouse growers are selling directly to consumers, there is still the incentive to supply local produce in summer months in areas where sufficient demand exists. Finally, in these traditional growing months, hoophouse growers are likely tending outdoor crops so we would expect an increased opportunity cost of working in the hoophouse.

Microeconomic theory predicts that profit-maximizing farmers will allocate their labor, so the marginal profit of $\mathrm{l} \mathrm{h}$ spent is equated across different activities: activities will vary according to their contribution to productivity in any given time period. In other words, one would expect the marginal profit of $\mathrm{l} h$ spent in the hoophouse to be equal to the marginal profit of other activities of the hoophouse grower, thus shifting and rotating labor allocation during the year. Each farmer would theoretically choose to allocate their time to maximize their profit given the relevant inputs and outputs and the opportunity costs of labor from other activities. Furthermore, one would expect the grower to allocate time differently from one season to the next as they learn how to use this tool more efficiently. Eventually, the marginal product of labor in the hoophouse

\begin{tabular}{llll}
\hline $\begin{array}{l}\text { Units } \\
\begin{array}{l}\text { To convert U.S. to SI, } \\
\text { multiply by }\end{array}\end{array}$ & U.S. unit & SI unit & $\begin{array}{l}\text { To convert SI to U.S., } \\
\text { multiply by }\end{array}$ \\
\hline 0.4047 & acre(s) & ha & 2.4711 \\
0.3048 & $\mathrm{ft}$ & $\mathrm{m}$ & 3.2808 \\
1.6093 & mile(s) & $\mathrm{km}$ & 0.6214
\end{tabular}


will equal or exceed the marginal product of labor from other activities. Farmers who are unable to make this happen, we would expect, would discontinue the technology.

The focus of this article is to explore the determinants of profitability of the hoophouse use on 12 Michigan farms and to understand how these novice hoophouse farmers made management decisions. It builds on a previous study (Conner et al., 2010) by using regression analysis and interviews to better understand how management decisions impact profitability. This study differs from the previous study in several key ways. First, this article includes data from three additional farmers who joined the study 1 year later than the original nine farmers. Second, the earlier article focused largely on descriptive statistics (e.g., frequencies and means) of several measures, including revenues, inputs costs, and labor devoted to construction and operation, with little discussion on how these measures interact. This study goes into greater depth on farm management, particularly how market and labor allocation decisions influence profitability. This study contributes to the literature by using mixed (quantitative and qualitative) methods and statistical analysis to provide an indepth picture of how 12 novice farmers use a potentially valuable tool to increase farm profitability.

\section{Materials and methods}

The data came from a group of 12 farmers who were selected to receive the same 30 -ft-wide by 96 -ft-long hoophouses and relevant training starting in July 2006, as part of a U.S. Department of Agriculture-funded research project conducted at Michigan State University. The farms were roughly located in four regions of Michigan (three farms in each region: southeast, western, northwest, and Upper Peninsula). Hoophouses were purchased with grant funds and retailed for $\$ 10,000$ each. In exchange for the hoophouses, the growers agreed to record detailed monthly revenues, input costs, and labor use related to the hoophouse for a period of $\approx 30$ months. Eleven of the 12 participating farmers were selected by recommendations from extension educators and other community partners who were instrumental in the overall project design. The 12th farmer joined the project $\approx 1$ year after it had begun (due to an original farmer choosing to drop out) and was selected by a request for applications process. During the autumn of each project year, on-farm interviews were conducted to collect information on what farmers were learning and doing in the hoophouse. The interviews were semistructured (Wengraf, 2001): the researchers had prepared a set of questions for each interviewee, yet diverged from them slightly as new issues emerged. Following the 30 months, semistructured interviews were also used to collect additional characteristic data from the farmers to be used in this article.

Research protocols were approved by Michigan State University's Institutional Review Board for Human Subjects Research. The farmers gained permanent possession of the hoophouse in exchange for collecting and sharing economic data and serving as a demonstration site and technical resource for other farmers interested in this technology. As per the protocols, economic analysis was limited to the hoophouse itself; no other farm financial data were shared so as to minimize risks to participating farmers. Finally, farmers were instructed to use the hoophouses to grow products that best suited the farms' marketing strategies and goals. Each farmer chose to grow a variety of vegetable crops, according to season, markets, and customer preferences.

Revenues and costs were recorded and sent to the research team on a monthly basis. Labor was recorded by the farmers in log books on the basis of the activity that was being performed (according to the following categories: preparation, establishment, maintenance, harvest, etc.). Effective wage was calculated by dividing total profit (revenues minus costs) by total owner-operator labor hours over the course of the study. Wages paid to the laborers were included as operating costs.

These data presented multiple challenges. First, the data were selfreported and previous research has found wide variation in the outcomes from hoophouse budgeting exercises even with trained university enumerators, and this variability is presumably exacerbated when farmers collect data (Conner et al., 2010). The second issue with the data was that farmers received hoophouses and started producing in different phases and thus all the data do not start or end in the same month (Fig. 1). Finally, the farmers in this sample were given this tool/technology without having to pay out of pocket, which means their incentive to be profitable is perhaps less than if they had purchased the structure.

First, descriptive statistics were used to measure how effective farmers were at paying themselves. Then we explored profitability in two different ways, first by looking at average accounting profits for the novice hoophouse growers and then by estimating a profit profile using regression analysis to isolate the importance of growing, harvesting, and marketing in a given month. A time profile was also created using regression analysis to see in which months farmers were investing their time and the relative importance of investing time in that month. We looked at different subsets of these data to better understand the relationship between labor use over time and profitability (high and low wage earners).

All else being equal, some farmers will be more profitable in a hoophouse or on outside acres because of certain individual characteristics such as experience, education, or ability and some farmers will be able to obtain higher prices for their products based on the demographics in the area where they are growing and/or selling their produce. From this study, we wanted to learn how labor allocation decisions were associated with success in the hoophouse. Regression analyses were used to estimate the accounting profits per month as well as controlling for the different time period when farmers started growing, and the individual characteristics of the farmers. By including a dummy variable for each farmer and by interacting all the farmer dummy variables with the labor variable, we were able to control for the individual effect of each farmer. Dummy variables for each month revealed, with respect to the least productive month, January (dropped), the effect of that month on profitability, all else being equal. The time trend of the data was also controlled with a variable that tracks each time period of the data, increased by 1 for each month the individual farmer has the hoophouse. The coefficients should also be interpreted with respect to the dropped dummy variable, Farmer 7 


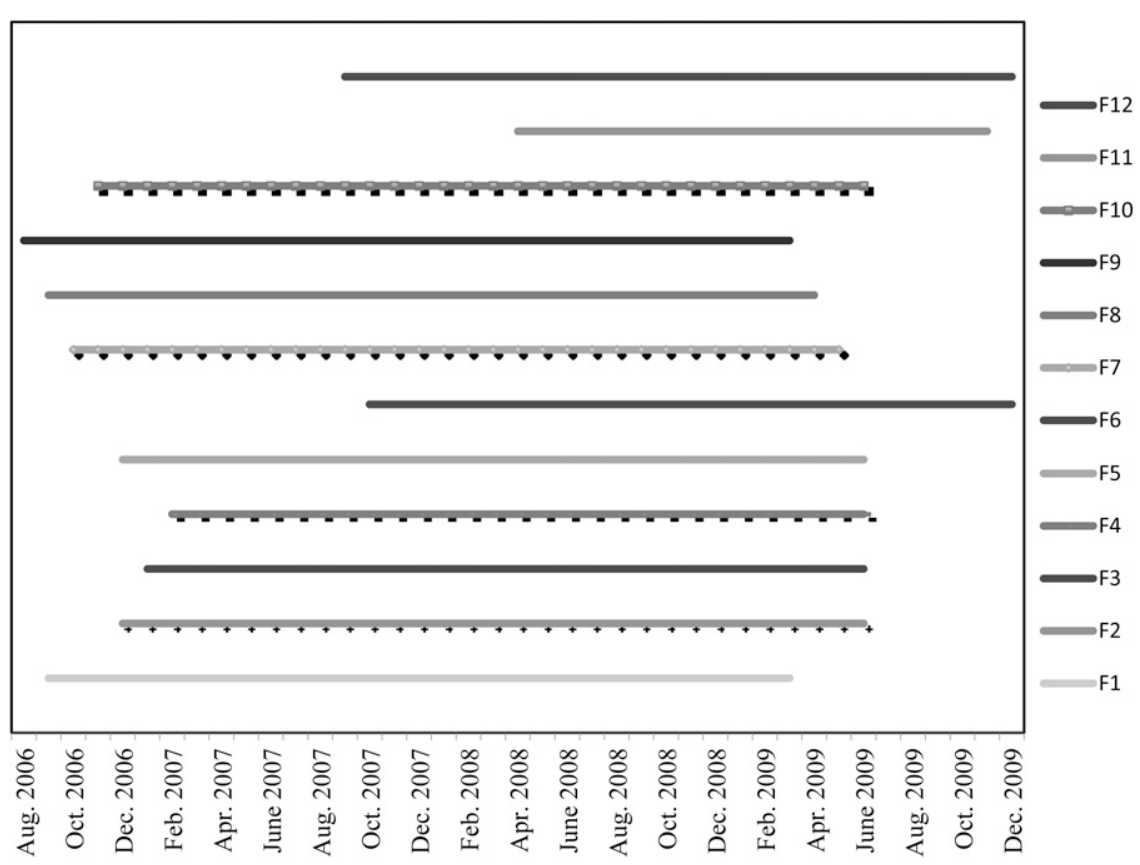

Fig. 1. Data collection time period for each of the 12 farmers (F1 through F12) who participated in the Michigan hoophouse case study (F1 through F12).

(F7) who was by far the least active and least profitable farmer in the group. We estimated Eq. [1] using a standard ordinary least squares (OLS) procedure, specified as follows:

$$
\begin{aligned}
\operatorname{Profit}_{f t}= & \alpha+\beta_{f} \text { Labor }_{f t}+\beta_{f} \text { Farmer } \\
& +\delta \text { Month }+\lambda \text { Time }_{f t}+\varepsilon_{f t} .[1]
\end{aligned}
$$

The profit of farmer $f$ in month $t$ (Profit $f t$ ) was modeled as a function of the number of hours allocated that month ( Labor $_{f t}$ ), the farmer dummy variables for each farmer (Farmer) and month (Month), and months of experience with the hoophouse ( Time $_{f t}$ ). Parameter vectors to be estimated were $\alpha, \beta, \delta, \lambda$, and $\epsilon_{f t}$ (a random error term). The time profile revealed in which months farmers were investing labor and how labor differs between months and over time. In the labor profile analysis, dummy variables were used for each month and for each farmer to isolate the variation that can be attributed to the time of year and the individual farmer characteristics (Eq. [2]). This is similar to a fixed effect model, where the within effect or individual effect is captured by each of the farmer dummy variables (Wooldridge, 2002). We were able to do this despite the small number of individual observations (12 farmers) because of the larger panel component to the data (30 months). The profile analysis for labor was specified as follows:

$$
\begin{aligned}
\text { Labor }_{f t}= & \alpha+\beta_{f} \text { Farmer }+\delta \text { Month }_{t} \\
& +\lambda \text { Time }_{f t}+\varepsilon_{f t} .[2]
\end{aligned}
$$

The labor in hours of farmer $f$ in month $t$ was modeled as a function of the dummy variable for each farmer (Farmer), month (Month), and months of experience with the hoophouse (Time T $_{f t}$ ). Parameter vectors to be estimated were $\alpha, \beta, \delta, \lambda$, and $\epsilon_{f t}$ (a random error term). Four separate regressions (A-D) were run using OLS to estimate the time profile of labor use in the hoophouses.

Regressions A-D were all specified by Eq. [2]. However, in regression A, only the data from year 1 (the first 12 months of observation for each farmer) were used, and in regression $\mathrm{B}$, only the data from year 2 (months 13-24 of observations for each farmer) were used. Regression C used the data of all months from the entire study. Regression D includes only farmers who had significant coefficients for their dummy variables in regressions $\mathrm{A}-\mathrm{C}$. The results are presented in Table 3 . The standard errors of each regression were all very similar because there is symmetry in the set of regressors (i.e., each month is correlated with every other month in the same way).

The coefficients on the month dummies measured how much labor farmers were used in that month relative to the dropped dummy variable, that is, January, when labor is zero or close to zero for most farmers (in some cases farmers use slightly less labor in December). This coefficient should be interpreted as the average number of labor hours that were contributed in each month holding all individual farmer demographics constant.

Semistructured interviews were used to understand why performance varied so widely and to try to understand what underlying management decisions contributed to this variation. A series of three annual semistructured qualitative interviews were conducted to reveal the characteristics of the participating farmers, including demographics and measures and descriptions of farm businesses and farming experiences and to understand how farmers were making management decisions over time. The qualitative data were used to explain the variation between farmers that we were not able to explain via quantitative analysis due to the limitations of the data set and to support the findings of the profit and labor profile regressions.

\section{Results}

Descriptive statistics. Farmer (F1 through F12) attributes used in the analysis are presented in Table 1. In addition to the wide variation in farmer attributes such as age, education, experience, and farm size, there was wide variation in the economic data collected (revenues, costs, profits, labor, wage) among hoophouse growers during the 30-month period (Table 2).

As shown in Table 2, there was extremely wide variation among the 12 farmers with almost half of the 12 farmers effectively paying themselves less than the minimum wage $(\$ 7.50 / \mathrm{h}$ in Michigan at the time of the study) while one farmer was making almost $\$ 24 / \mathrm{h}$. The wide variation was apparent when comparing farmers F2 and F6, who reported the highest total gross sales. Although their revenues were similar, F6 reported costs twice as high as F2. Furthermore, F6 reported considerably more of his own labor hours being used, leaving F6's effective wage nearly one-third of F2's effective wage. Fl2, who had the 
Table 1. Attributes of the 12 farmers (F1-F12) who participated in the Michigan hoophouse case study and their counties in 2010 .

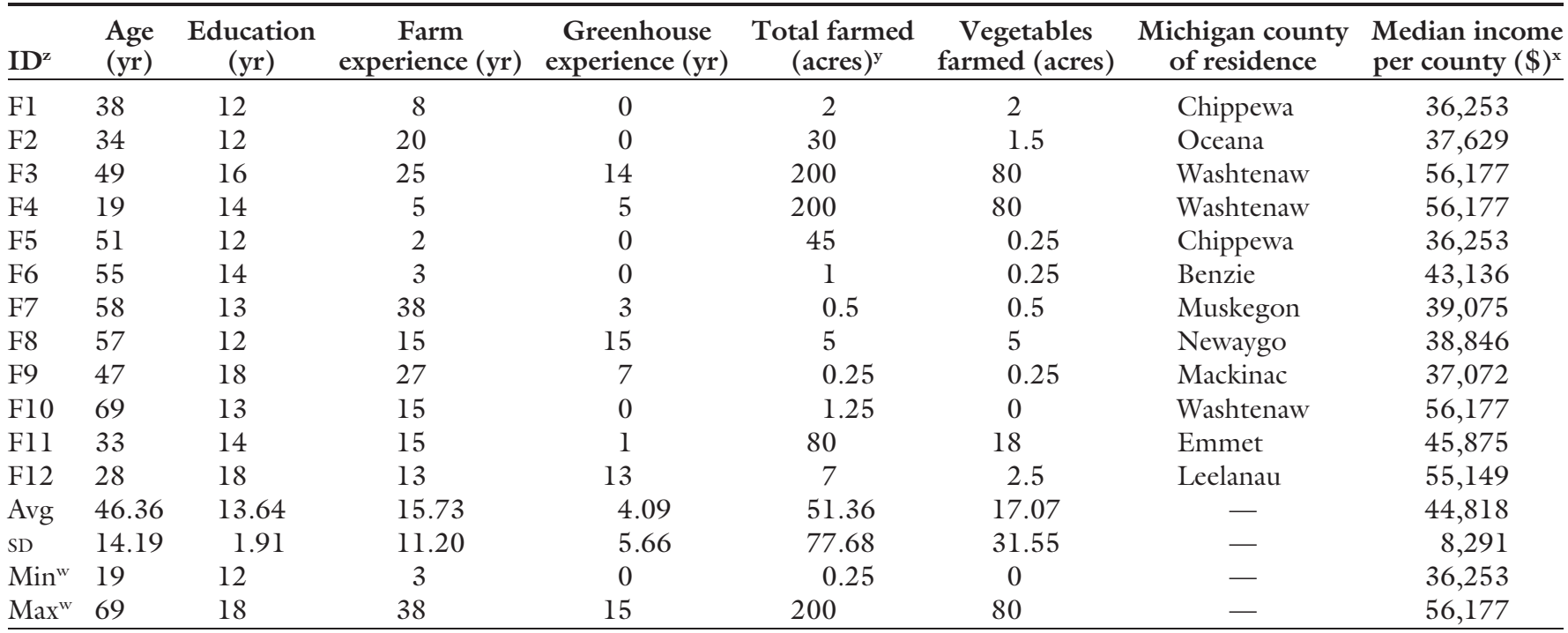

'Participating farmer's identification code.

y acre $=0.4047$ ha

${ }^{x}$ Median household income from U.S. Department of Agriculture (2011) is calculated as thousands for ease of interpretation in the regressions.

${ }^{\mathrm{w}} \mathrm{Min}=$ minimum observation, $\mathrm{Max}=$ maximum observation

Table 2. Selected data on economic performance of hoophouses collected from 12 Michigan farmers (F1-F12) who participated in the case study over the entire 30-month study period.

\begin{tabular}{lrrrrr}
\hline ID & \multicolumn{1}{c}{$\begin{array}{c}\text { Gross } \\
\text { revenues }(\$)\end{array}$} & $\begin{array}{c}\text { Total } \\
\text { costs }(\$)\end{array}$ & $\begin{array}{c}\text { Total } \\
\text { profit }(\$)\end{array}$ & $\begin{array}{c}\text { Total } \\
\text { labor }(\mathbf{h})\end{array}$ & $\begin{array}{c}\text { Effective } \\
\text { wage }(\mathbf{S} / \mathbf{h})\end{array}$ \\
\hline F1 & $8,892.50$ & $2,967.00$ & $5,925.50$ & $3,074.5$ & 1.93 \\
F2 & $20,320.09$ & $3,420.80$ & $16,899.29$ & $1,207.8$ & 13.99 \\
F3 & $6,269.60$ & $3,202.42$ & $3,067.18$ & 264.4 & 11.60 \\
F4 & $5,600.40$ & $3,005.84$ & $2,594.56$ & 327.5 & 7.92 \\
F5 & $6,963.16$ & $1,482.70$ & $5,480.46$ & 752.3 & 7.28 \\
F6 & $22,256.25$ & $7,056.20$ & $15,200.05$ & $1,807.5$ & 8.41 \\
F7 & $2,400.00$ & $2,049.95$ & 350.05 & $1,241.3$ & 0.28 \\
F8 & $4,414.25$ & $2,237.51$ & $2,176.74$ & 420.1 & 5.18 \\
F9 & $9,122.01$ & $4,856.75$ & $4,265.26$ & $1,315.3$ & 3.24 \\
F10 & $18,897.00$ & $3,638.20$ & $15,258.80$ & $1,590.9$ & 9.59 \\
F11 & $14,887.91$ & $5,675.49$ & $9,212.42$ & 508.0 & 18.13 \\
F12 & $17,398.15$ & $5,983.09$ & $11,415.06$ & 646.8 & 23.87 \\
Avg & $11,451.78$ & $3,798.00$ & $7,653.78$ & $1,096.4$ & 9.29 \\
SD $_{\text {Min }}^{y}$ & $6,893.09$ & $1,724.91$ & $5,768.30$ & 806.3 & 6.83 \\
Max $^{\mathrm{y}}$ & $2,400.00$ & $1,482.70$ & 350.05 & 264.4 & 0.28 \\
\hline
\end{tabular}

Participating farmer's identification code.

${ }^{\mathrm{y}} \mathrm{Min}=$ minimum observation, $\mathrm{Max}=$ maximum observation.

highest effective wage over the 30 month period, had relatively lower profits (lower revenues and higher costs) but very low labor hours. F11 had similar costs to F12 but generated less revenue and ultimately had an effective wage that was significantly less than that of F12. It also should be noted that F7 had revenue almost equal to the costs (both small or near zero, demonstrating minimal effort overall) and thus an effective wage which was almost zero, while farmer Fl put in so much labor (more than $3000 \mathrm{~h}$ labor over the course of the study, almost 10 times that reported by farmers F3 and F4) that the effective wage was also negligible. Overall, profit was positively related with gross sales and there was a smaller range of variability among costs than sales. It is also clear which farmers would have been able to pay back for the hoophouse structure from their profits by the end of the study period (F2, F6, F10, and F12).

There appears to be a negative relationship between age and high effective wage, suggesting diminishing returns to age in this sample. The three highest effective wage earners were in range of 28 to 34 years old. Level of education ranged from General Equivalence Diploma to Master of Science degree and does not have any clear connection to effective wage with the exception that the highest wage earner has an MS degree in horticulture. Years of farming experience ranged from 2 to 38 years, and some farmers with many years of experience performed less well than the farmers with little to no experience. The median household income per county where hoophouses were located ranged from $\approx \$ 40,000$ to $\$ 60,000$ per year and is not correlated with effective wages.

Average accounting profits OVER TIME. Monthly average accounting profits, calculated as total gross sales less costs (excluding costs of own labor), were calculated for the 12 farmers. However, the average figures do not properly represent the change in average profit over time because the farmers received the hoophouses and started growing at different times between Aug. 2006 and Mar. 2008 (Fig. 1). For this reason the learning 
Table 3. Factors influencing hoophouse labor allocation by the 12 Michigan farmers (F1-F12) who participated in the case study. Regressions A and B use the first and second years of data for each farmer, respectively. Regression C uses all available data, whereas regression D uses data only from the farmers with significant identifier variables in regressions A-C. ${ }^{\mathrm{z}}$

\begin{tabular}{|c|c|c|c|c|c|c|c|c|}
\hline \multirow[b]{2}{*}{$\underline{\text { Variable }}$} & \multicolumn{2}{|c|}{ (A) Yr 1 labor $_{\mathrm{f}}$} & \multicolumn{2}{|c|}{ (B) Yr 2 labor $_{\mathrm{f}}$} & \multicolumn{2}{|c|}{ (C) All years labor ft } & \multicolumn{2}{|c|}{ (D) All years labor ${ }_{\text {high }}$} \\
\hline & Estimate & SE & Estimate & SE & Estimate & $\mathrm{SE}$ & Estimate & SE \\
\hline February & -0.0483 & 11.422 & 13.157 & 12.435 & 5.69 & 8.058 & 9.026 & 12.233 \\
\hline April & $35.314^{*}$ & 11.446 & $27.339 * *$ & 12.417 & $33.063^{*}$ & 8.136 & $40.413^{*}$ & 12.054 \\
\hline May & $49.919 *$ & 11.517 & $48.91 *$ & 12.625 & $51.423^{*}$ & 8.209 & $54.026^{*}$ & 12.075 \\
\hline June & $47.859 *$ & 11.634 & $27.701 * *$ & 12.899 & $42.966^{*}$ & 8.286 & $45.748^{*}$ & 12.288 \\
\hline September & 14.246 & 11.517 & $28.277 * *$ & 13.020 & $26.896^{*}$ & 8.353 & $25.229 * *$ & 12.814 \\
\hline October & $19.808 * * *$ & 11.446 & 9.6454 & 12.610 & $20.394^{*}$ & 8.205 & 30.21 * & 12.072 \\
\hline November & 9.569 & 11.446 & 8.517 & 12.865 & 8.316 & 8.135 & 11.132 & 11.878 \\
\hline December & 6.353 & 11.422 & -7.063 & 12.741 & -1.638 & 8.063 & 1.166 & 11.855 \\
\hline Fl & $31.316^{*}$ & 11.422 & $86.806^{*}$ & 12.153 & $62.799 *$ & 8.130 & - & - \\
\hline F6 & $43.854^{*}$ & 11.422 & $60.909 *$ & 12.153 & $43.697^{*}$ & 8.198 & $44.011^{*}$ & 8.505 \\
\hline F8 & -12.782 & 11.422 & -18.801 & 12.153 & $-24.885^{*}$ & 8.058 & - & - \\
\hline F9 & $26.719 *$ & 11.422 & 4.521 & 12.148 & 7.709 & 8.063 & - & - \\
\hline F10 & $19.604 * *$ & 11.422 & $20.1752 * * *$ & 12.146 & 10.22 & 8.058 & 10.4403 & 8.098 \\
\hline F11 & $33.55^{*}$ & 11.422 & -9.792 & 13.536 & 8.086 & 9.286 & 8.086 & 9.472 \\
\hline F12 & 14.564 & 11.422 & -19.364 & 12.153 & -12.362 & 8.357 & -14.175 & 8.504 \\
\hline Months in hoophouse & 0.633 & 0.737 & 0.6874 & 0.942 & $0.7151^{*}$ & 0.197 & 0.742 * & 0.299 \\
\hline Constant & -0.872 & 11.754 & 3.684 & 19.094 & 5.028 & 8.488 & 1.211 & 10.902 \\
\hline Observation & 144 & - & 129 & - & 355 & - & 135 & - \\
\hline$R^{2}$ & 0.506 & - & 0.686 & 一 & 0.508 & - & 0.3488 & - \\
\hline
\end{tabular}

${ }^{2 *},{ }^{* *},{ }^{* *}$ Significant as measured by $T$-values in regression at $0.01,0.05$, and 0.10 , respectively.

curve is distorted (perhaps dampened) as new farmers begin growing while other farmers are making gains from learning. Furthermore, costs are accrued immediately while revenues are realized $\approx 2$ to 3 months later. Despite these potentially confounding factors, a very clear seasonal pattern emerges (Fig. 2). Farmer profits peak in May and then slowly decline over the summer months until a small bump in profits in the late summer/ early fall when a second crop is harvested. There is also an average annual increase in profits over time.

Profile analysis of HOOPHOUSE PROFITs. A graph of the month coefficients from this regression is presented in Fig. 3. The coefficient estimates can be used to determine the effect of a given month on profit.

We see the same general shape as in the average profits calculated in Fig. 2. Farmers are able to use the hoophouse to get a jump on the outdoor growing season, seeing their largest profits in the month of May. The profits drop back down to about half of the peak during summer months (June, July, and August) before the profits go down to a much lower level in the fall/early winter. Minimal profits are made in October, November, and December.

Profile analysis of Labor USe IN HOOPHOUSES. Regressions (A) and (B) in Table 3 compare labor use in the hoophouse in years 1 and 2 by using subsets of the data as described earlier. In regression (A), the first year of reported data, months April to July are large and significant at the $1 \%$ level. In regression (B), reflecting year 2 of the study, the results are significant from March to September (with the exception of July). The winter quarter is still insignificant (in both regression estimates). In Fig. 4, the magnitudes of these two regressions are compared. It appears that in year 2, farmers invested more labor in the lead shoulder of February and March (more than double) and again in August and September to prepare for growing in the (fall) shoulder of the season. In year 2 , they also invested less time in the hoophouse during the height of the summer (in June and July) and later in October and December.

Regression (C) uses the data for all farmers across 30 months, which is compared with regression (D) which is the subset of farmers with the highest effective wages (above minimum wage). In both regressions, the same set of months is significant and only the winter months are not significant at any level. This comparison demonstrates that, with all else equal, the high wage group of farmers (with respect to the dropped F7) will use on average more labor over the course of the year $(\approx 3 \mathrm{~h}$ more per month in February, May, June, August, November, and December).

On the basis of these results, higher wage earners on average use $\approx 3 \mathrm{~h}$ more per month than the lower wage earners, all else being equal (which is the case in 6 of the 12 months). In March, April and then again in October, higher wage earners devote $\approx 10 \mathrm{~h}$ more than the rest of the group, evidence that those may be key months 


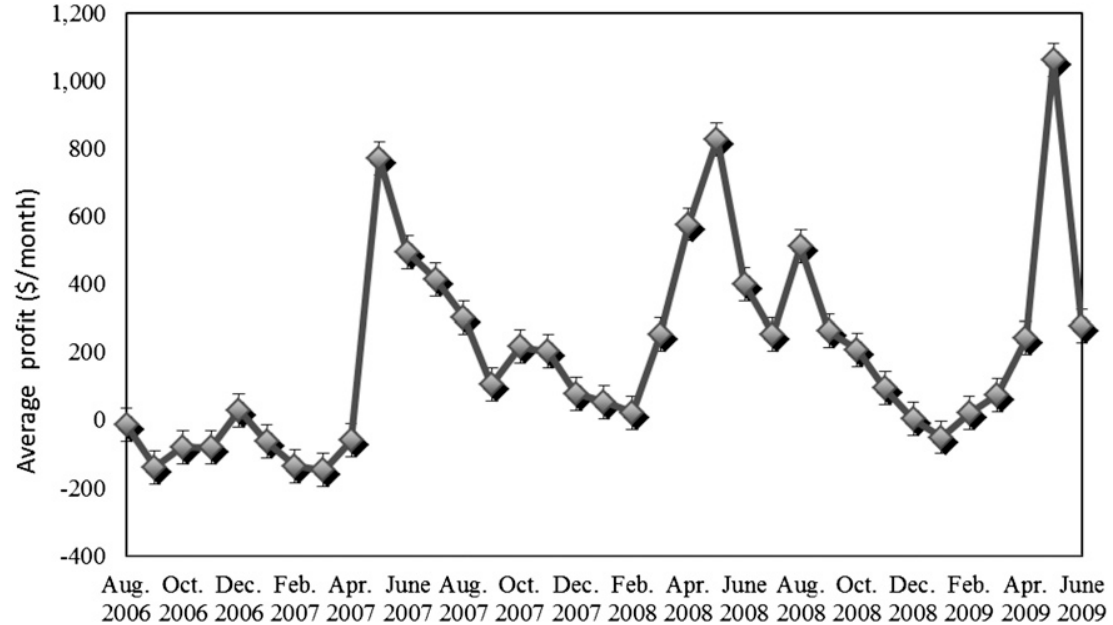

Fig. 2. Average monthly accounting profits over time $( \pm S E)$ for the 12 farmers who participated in the Michigan hoophouse case study.

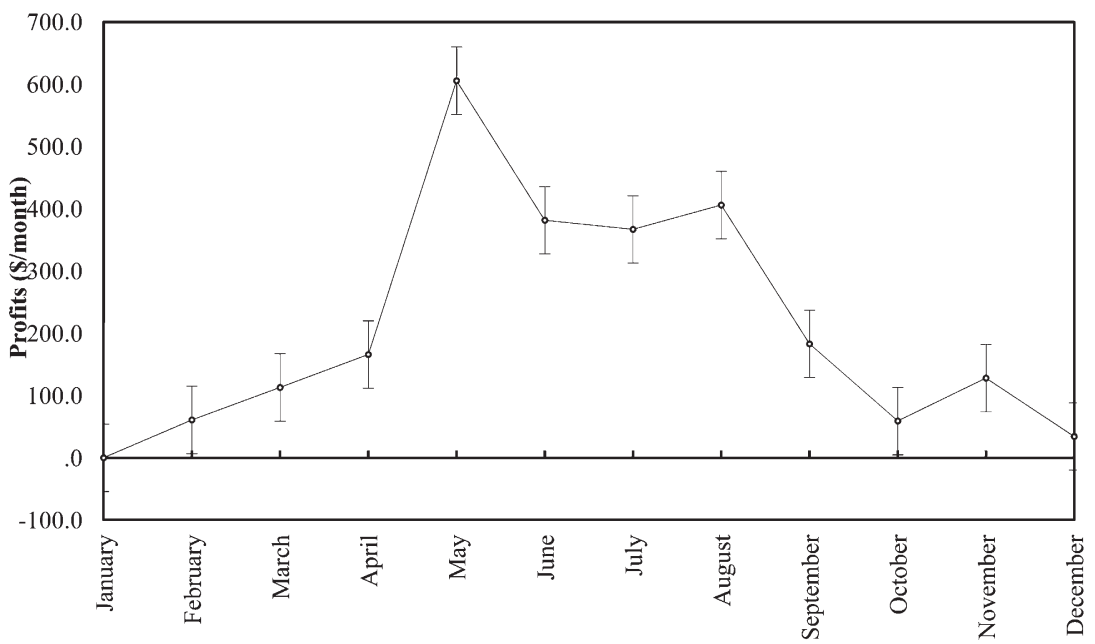

Fig. 3. Profile of accounting profit using regression coefficients $( \pm$ SD) for the 12 farmers who participated in the Michigan hoophouse case study.

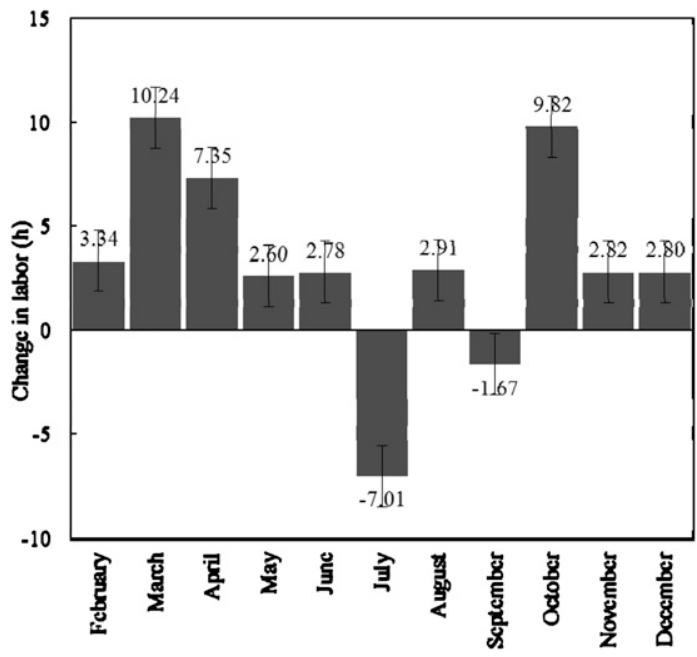

Fig. 4. Difference in hours of labor by month between all farmers (regression C) and high wage earners (regression $D)$ for the second year of the study $( \pm S E)$ from the 12 farmers who participated in the Michigan hoophouse case study. where the marginal product of labor may be higher. Higher wages are associated with a broadening of the lead shoulder, not just in February and March but also extending into April. High wage earners also use much less labor in July. Comparing year 1 to year 2 data, there is an increase in August and September, while based on Fig. 3, higher wage earners also continue the labor push through October. In both the shoulders, it seems that higher wage earners broadened the shoulders by 1 month than the rest of the group (in March/April and October) instead of just a single labor push in February and then in August/ September.

The coefficients on the farmer dummies in these regressions indicate, with respect to the least productive farmer (dropped F7), how much labor is used by each farmer: relatively speaking how much time farmers devoted to hoophouse production as compared with others in the sample. Farmers Fl and F6 are the heaviest labor users overall, with large positive coefficients significant at the $1 \%$ level in all regressions. Farmers F3 and $\mathrm{F} 4$, the farmers with the largest farms, clearly use less labor in the second year than the first as the coefficient is large, negative, and significant at the $1 \%$ level in the second year (regression B) and in all years (regression C). Farmers F9, F10, and Fll have significant coefficients in the first year, but these variables are not significant in the subsequent regressions, leaving interpretation difficult. We also see from the months in the hoophouse variable that for each additional month, farmers use roughly $3 / 4 \mathrm{~h}$ more labor in the hoophouse over the course of 30 months.

HOOPHOUSE MANAGEMENT. Interview responses first focused on what farmers changed in production over the course of the study, particularly timing of crops, including "starting a little earlier" and "more winter and less summer." These comments support what we were seeing for the higher effective wage earners in the profit and labor profile regressions. When farmers were visited in January of last year of the project, the two highest wage earners, F11 and F12, had full hoophouses and were clearly pushing into winter months. The highest wage earner had already purchased another hoophouse and had 
not harvested in the hoophouse studied in our project since August, to have a full winter crop for CSA sales. The responses to capacity of the hoophouse used (percentage in time and space) reflect strong correlation with effective wages. For example, the highest wage earners reported 100\% full (F12), 12 months of the year, 80\% full 12 months of the year (F11), and $100 \%$ all but "a few weeks for fallow" (F2). This suggests for new farmers that a very simple yet important determinant of success is whether they are able to keep the hoophouse full.

As was expected, farmers reported a significant learning process and continued experimentation through the end of the project. In response to what farmers learned over the course of the project, the most frequent responses were learning which crop and mix of crops are most profitable (in many cases salad greens were at the heart of this). Farmers appeared to be developing systems, such as planting in stages (F12), "simplifying what they are planting," and "focusing on more profitable crops like greens." Even by the end of year 3, farmers reported learning through experimentation with overwintering (F7); drip tape, soaker hoses, and hanging baskets (F6); watering systems (F11); and canning and drying produce $(\mathrm{Fl})$.

QUALITY OF LABOR. Only three of the 12 farmers reported high diligence with controlling weeds in the hoophouse, a management factor associated with profitability and labor efficiency. Notably though, the lowest self-reported figures for weed control were the two lowest wage earners and the highest wage earner (F12) who ascribed to "more of a permaculture approach." The group was split between those that had overhead or drip watering systems and those that watered by hand. Those that had watering systems reported "time savings" and "more comfort for crops," although two others reported that overhead systems led to overwatering for some crops (including highest wage earner). In terms of pest management, only two farmers reported less than four out of five on a Likert scale, and these were two of the lowest wage earners. However, it appears that farmers either did not experience serious pest problems or experienced a little and worked to address them, which led them to report less than five out of five. Compost was cited as the most common way to build productive soil and combat pests, although some farmers used homemade spray remedies with mixed results.

Based on the differences in labor use between the data from an average of all farmers with the (normalized) data for farmer Fl2 (the highest effective wage earner) (Table 3), Fl2 spent more time on planting (although this was seeding and transplanting as opposed to bed preparation and fertility management) than on maintenance [although he spent relatively more time on crop maintenance than average, which includes miscellaneous activities such as trimming dead leaves and trellising tomato (Solanum lycopersicum) plants]. F12 spent a similar amount of time as the average farmer on harvestrelated activities, but all this time was reported as actual crop harvest and not on packing and washing.

The relatively higher amount of time spent on seeding, transplanting, maintenance, and harvesting activities may be an indication that farmer F12 was more successful simply because one has to plant to be able to make money, and this farmer put more plants in the ground and spent time in maintaining and harvesting it.

Hired labor. More than half of the farmers used only themselves or unpaid family labor in the hoophouse, a few reported occasional hiring of labor, two reported hiring regular interns, and the largest farm hired outside labor for all harvesting. The two highest wage earners (Fll and Fl2) hired "interns" who were involved in all hoophouse activities and paid them $\$ 8.50 / \mathrm{h}$ to $\$ 10.00 / \mathrm{h}$ (depending on whether room and board was included and whether they were international interns). Farmers who simply hired labor for specific tasks (including packing/washing, harvesting, etc.) paid the workers between $\$ 6 / \mathrm{h}$ and $\$ 8 / \mathrm{h}$. One farmer hired labor only to shovel the snow off the hoophouse. The farmer with the largest outdoor field acreage (and hoophouse planted just a single crop) hired labor only for harvesting and was thinking about hiring migrant labor in the future. Specific experiences related to the quality of hired labor reported during interviews appear to explain why F11 and F12 did well while F3 and F6 may have benefited less from hired labor.
Record KeEPING. Farmers who reported the most difficulty turning in records on average had lower effective wages, a possible indication that organization skills are important to effective management. The most organized farmers [submitted timely and neat records-self-reported five out of five on a Likert scale in both categories (F2, F8, F9, and F10)] made steady profits, but ultimately ranged in effective wages. The variation for this subgroup appeared to be correlated with age, with the youngest having the highest effective wage. The middle group consisted of two of the highest wage earners (F11, Fl2) and one of the lowest wage earners (Fl), confounding clear interpretation of the relationship of record keeping to hoophouse success. Incidentally, the farmers in the most organized group found that the records "helped them decide what to grow" and "helped [them] think about crop rotations, and revenue per square foot profitability." In general, the more successful farmers reported applying lessons that emerged from record keeping. The least organized farmers (selfreported one or two on a five-point Likert scale) reported a range of responses about the utility of the records. The two lowest wage earners "just had a feeling about things" and found the records "to be a nuisance." The other two farmers in this group thought the records helped inform their actions but did not collect them perhaps simply due to organizational/ time management issues (being overstretched). For the group in the middle, the highest wage earner (F12) was already keeping "ecological records" but felt the required record keeping complemented his own records ( $\mathrm{Ta}-$ ble 4$)$. The second highest wage earner (who also has multiple agricultural enterprises including a farm store, agritourism business, and restaurant) used a much larger amount of labor and kept records when he started farming full time, but chooses not to now.

HoOpHOUSE MARKETS AND MARKET CONDITIONS. Market conditions faced by the sample of hoophouse growers and market strategies differed with some farmers expanding the number of farmer's market attended, whereas other farmers improved the performance in one farmer's market. Most farmers reported little 
Table 4. Comparison of the mean labor allocation to each activity category by all Michigan farmers (F1-F12) who participated in the hoophouse case study with the allocation of F12 (highest wage earner).

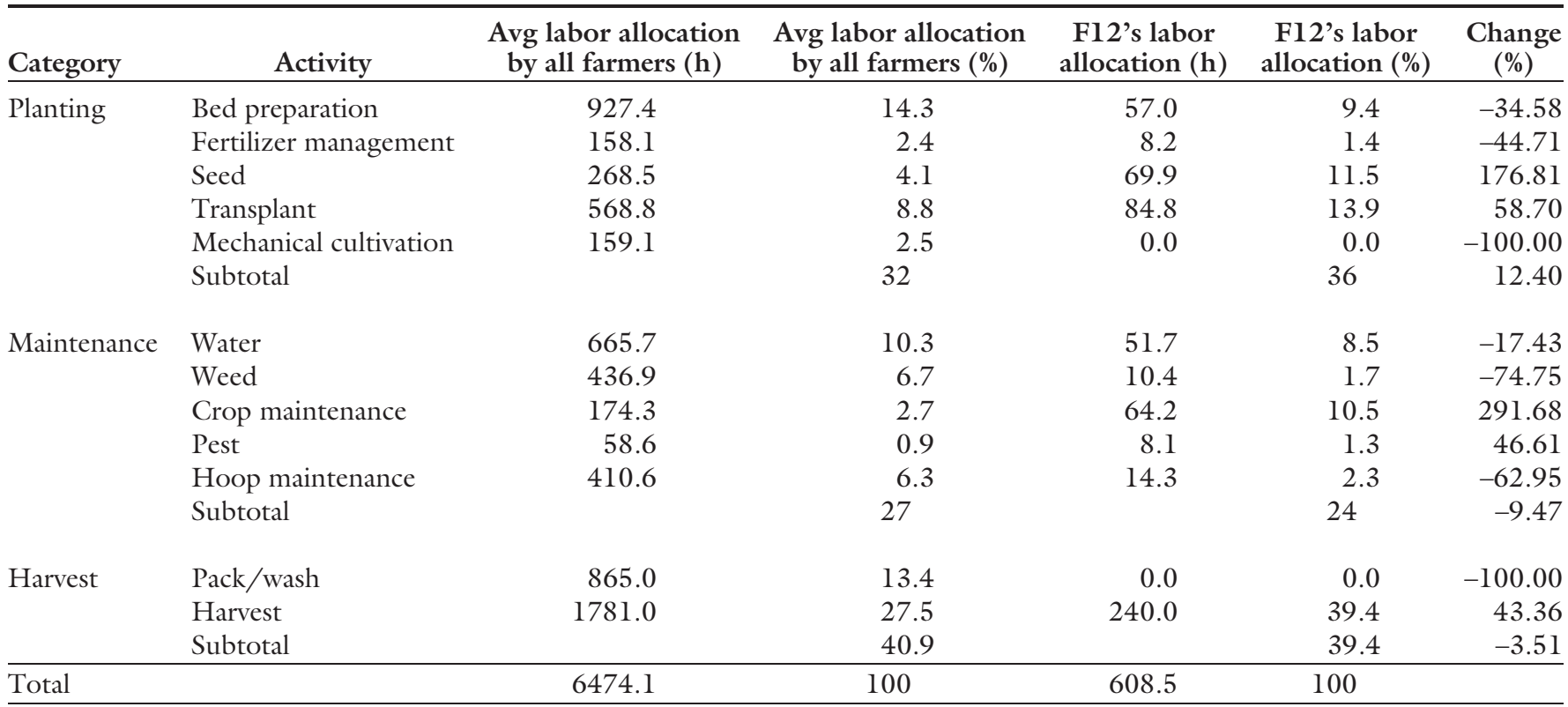

problem in selling all harvested crops whenever a market was open, but few areas have year-round markets and if they do, they are not well trafficked in the shoulders of the season. Four farmers reported selling $100 \%$ of produce they take to the farmer's market while others reported slightly less (greater than 85\%); farmers who were specialized in salad green sold slightly less than $85 \%$. Three farmers in the Upper Peninsula reported the lowest percentages, below $50 \%$, but overall qualitative findings suggest that farmer's markets are at this point saturated with produce from other areas. In terms of farmer's market growth over the timeline of the project, Upper Peninsula farmers reported deteriorating conditions, whereas northwest and southeast growers reported robust sales. A farmer in the western Michigan area reported growth (F2), a second reported decline (F8), and a third reported sales down due to increased competition from new vendors, but greater "customer participation" (F6).

All three Upper Peninsula farmers pulled away from farmer's markets reportedly due to a lack of demand for fresh local produce and competition with vendors importing fruit and vegetables from other places further south. Two of these farmers had other full-time jobs, suggesting that the wages from other employment exceeded the wages farmers made in the hoophouse. But other than the Upper Peninsula farmers, farmers were not changing markets or made small changes such as adding a CSA or attending a new farmer's market. A clear finding is that CSA or similar arrangements that involve direct sales to customers seem to be the most profitable method of selling produce, and farmers in difficult regions (remote areas in Upper Peninsula) are moving toward on-demand type harvesting/selling. The most profitable farmer (F12) markets produce in the second highest income county in the sample and had a CSA before the hoophouse. He stated that, "a CSA means that I do not harvest anything I have not already sold."

Two farmers reported disputes with other farmers or farmer's market managers, which affected their participation in the farmer's market. In one market, there were conflicts among vendors disputing the use of "organic" in describing the market as a whole while not all vendors were certified organic. On the other hand, three farmers reported synergy between fresh vegetables and other products they were already selling at farmer's markets; one farmer found a positive association with his herbal products (F6) and another for meat (F2). The average distance traveled to market was $\approx 26$ miles, but the proximity to market alone was not a major determinant of success. For example, the farmer in the region with the second lowest median income per county (F2) had the third highest effective wage, drove 50 miles to one market per week, and also sold meat at the market.

Overall, seven farmers made market outlets work for their hoophouse products, two exited the hoophouse business, and three relied on CSA arrangements in the 3 -year period of the study. The interview data may explain why all farmers do not appear to be using the shoulders as we might have expected. The presence of markets is an important determinant of when it would be profitable to invest labor in the hoophouse. If Upper Peninsula farmers know they are not going to have any direct market venues to sell their produce, it does not make sense for them to make use of the shoulders of the season. In contrast, if F11 and F12 perceive a robust year-round market, then it is more profitable for them to push production into the shoulders of the season. The other implication of the interview data is that farmers appear to be moving away from planting decisions on the basis of single crop profitability (highest revenue per square foot) toward a CSA mindset (basing production decisions on the basket they believe customers desire). This 
may explain why farmer behavior appears to be different than what microeconomic theory would predict. In other words, farmers who were making profits selling only salad mix at the farmer's market, which closes during the winter, do not make use of winter months in the hoophouse, whereas farmers with developed CSAs produce throughout the season with lower profit margins because they are focused on spreading harvesting and profits throughout the year.

\section{Conclusions}

We report on the economic outcomes of 12 novice hoophouse farmers using hoophouses for season extension in Michigan. Descriptive statistics reveal a broad array of revenue, labor, and cost outcomes. From the summary statistics, we know that the farmers with the highest total accounting profit do not earn the highest effective wage. When we look more closely, we see that some farmers with high effective wages do not have the most efficient labor profiles. There is a range of time when labor is most profitably used. Both estimations reveal that the hoophouse farmers were more profitable using more labor in the early shoulder months, particularly in February and March and then again in August and September. Based on these data, it was more profitable not to increase labor use in the summer and specifically to reduce labor use in July possibly due to a shift of labor to the field. On the whole, the more profitable group focused overall on a larger labor push in October either for harvesting crops or for planting crops for winter harvest. These quantitative results along with the supporting qualitative interview data have implications for future hoophouse growers who may not be confident that they can produce profitably in the winter months. More generally stated, broad shoulders are associated with higher profits.
Based on the semistructured interview data, formal education and prior hoophouse or greenhouse experience are not strong determinants of success. Farmers need to consider the time spent on various tasks or activities. A simple but important finding is that hoophouse success is predicated on keeping the hoophouse full, which requires a labor or effort focus on planting and harvesting. Also, spending a lot of time on weeding and watering will increase labor expense quickly in the hoophouse, which supports the use of preventative weed management and irrigation systems. These data were not constructed for deep exposition of this question, but comparison among these 12 novice hoophouse growers leads us to suggest that a possible area of future research is to determine what factors influence the profitability of specific crops.

There is inconclusive evidence of whether record keeping results in better hoophouse management. But for both newer and experienced farmers, record keeping can be beneficial as a means to inform crop mix and space allocation decisions. Record keeping alone is not the key to success as organizational skills must be paired with labor efficiency to return a high effective wage.

Market outlets are important to profitability, but they are not the most important factor. Growers in the Upper Peninsula were able to adapt to poor market conditions and still make reasonable profits although with considerably more difficulty than the growers in other areas. Hoophouse production is both a specialized and time-intensive activity that requires skilled labor and microlevel management, a technology that is not for everyone and may not be easily adopted by farmers who lack a background or skills in horticultural production.

Future research should focus on an improved data collection process and aim for a much larger sample size. Given the limitations of the data and the emphasis on the outreach component of this grant, we feel that taking a broad look at labor use in hoophouses is a good first step in building the literature on the economics of hoophouse production and will pave the road for important research on the economics of diversified hoophouse crop production.

\section{Literature cited}

Blomgren, T. and T. Frisch. 2007. High Tunnels: Using Low-cost Technology to Increase Yields, Improve Quality, and Extend the Season. 5 Mar. 2012. <http:// www.uvm.edu/sustainableagriculture/ Documents/HighTunnels.pdf $>$.

Cheng, M. and W. Uva. 2008. Removing Barriers to Increase High Tunnel Production of Horticultural Commodities in New York. Economic and Marketing Study Final Report. 1 Mar. 2012. <http: //www.hort.cornell.edu/hightunnel/ about/research/economics/removing_ barriers_uva_cheng.pdf $>$.

Conner, D., K. Waldman, A. Montri, M. Hamm, and J. Biernbaum. 2010. Hoophouse contributions to economic viability: Nine Michigan case studies. HortTechnology 20(5):877-884.

Heindenreich, C., M. Pritts, M.J. Kelly, and K. Demchak. 2009. High Tunnel Raspberries and Blackberries. I Mar. 2012. <http://www.fruit.cornell.edu/berry/ production/pdfs/hightunnelsrasp2009. pdf>.

U.S. Department of Agriculture. 2011. County-level Unemployment and Median Household Income for Michigan. 1 Mar. 2012. <http://www.ers.usda.gov/data/ unemployment/RDList2 .asp!ST=MI>.

Wengraf, T. 2001. Qualitative research interviewing: Biographic narratives and semi-structured methods. Sage Press, London.

Wooldridge, J.M. 2002. Introductory econometrics: A modern approach. South Western Publishers, Mason, OH. 